\title{
HOME CHILDBIRTH: PROGRESS OR RETROCESSION?
}

Clara Fróes de Oliveira SANFELICE ${ }^{\mathrm{a}}$, Antonieta Keiko Kakuda SHIMO ${ }^{\mathrm{b}}$

ABSTRACT

Giving birth at home represents a rising modality of delivery care in the Brazilian society, although in unrepresentative proportion when compared to the number of hospital childbirths. In Brazil, the topic has been broadly discussed by different professional categories, highlighting the safety issue involved in the process. The aim of this theoretical and reflective study was to present a brief overview of the overall care related to home childbirth, also questioning the reality of the contemporary Brazilian obstetric scenario. The scientific literature presents both obstetric and neonatal outcomes as favorable to home childbirth; similar risks when compared to hospital childbirth and higher rates of maternal satisfaction, and these both factors justify its practice. Therefore, a movement of women who are deeply unhappy with the current model of obstetric care is currently observed and they have been opting for home childbirth as a response to institutional violence, fragmentation and depersonalization of hospital care.

Descriptors: Midwifery. Humanizing delivery. Home childbirth.

\section{RESUMO}

Parir em casa representa uma modalidade de atenção ao parto em ascensão na sociedade brasileira atual, embora em proporção pouco representativa quando comparada ao número de partos hospitalares. No Brasil, o tema tem sido amplamente debatido por diferentes categorias profissionais, com destaque para a questão da segurança envolvida no processo. Este artigo, de cunho teórico-reflexivo, tem como objetivo apresentar um breve panorama global da assistência ao parto domiciliar, problematizando a realidade do cenário obstétrico brasileiro contemporâneo. A literatura científica apresenta resultados obstétricos e neonatais favoráveis ao parto domiciliar, risco semelhante quando comparado ao parto hospitalar e maiores índices de satisfação materna, fatores que legitimam a sua prática. Assim, observa-se, na atualidade, um movimento de mulheres que, profundamente descontentes com o modelo de atenção obstétrica vigente, têm optado pelo parto em casa como reação à violência institucional, à fragmentação e despersonalização da assistência hospitalar.

Descritores: Tocologia. Parto humanizado. Parto domiciliar.

Título: Parto domiciliar: avanço ou retrocesso?

\section{RESUMEN}

Dar a luz en casa es un tipo de atención del parto en aumento en la sociedad brasileña, aunque en proporción no representativa en comparación con el número de nacimientos en hospitales. En Brasil, el tema ha sido ampliamente debatido por diferentes categorías profesionales, destacando el problema de seguridad en el proceso. Este artículo, teórico-reflexivos presenta una breve visión general del parto en casa, cuestionando la realidad del contexto obstétrico brasileño contemporáneo. La literatura científica muestra resultados obstétricos y neonatales favorables para el parto en casa; riesgo similar en comparación con el parto en el hospital y tasas más altas de satisfacción materna, factores que legitiman su práctica. Así, vemos, en realidad, el movimiento de mujeres, que profundamente descontentos con el actual modelo de atención obstétrica, han optado por el parto en casa como una reacción a la violencia institucional, la fragmentación y la despersonalización de la atención hospitalaria.

Descriptores: Tocología. Parto humanizado. Parto domiciliario.

Título: Parto en casa: hacia adelante o hacia atrás?

\footnotetext{
a Obstetric nurse, Doctoral student at the Nursing Graduate Program of the Nursing School, State University of Campinas. Campinas/SP/ Brazil.

b Obstetric nurse, Ph.D. Professor at the Undergraduate Course and the Graduate Program of the Nursing School, State University of Campinas. Campinas/SP/Brazil.
} 


\section{INTRODUCTION}

Currently, childbirth care in Brazil is characterized by a hegemonic and technocratic model coupled with a high rate of cesarean sections and delivery institutionalization ${ }^{(1)}$, which results in worse maternal and perinatal outcomes than those found in countries with equal or lower levels of socioeconomic development ${ }^{(2)}$.

According to statistics, over $98 \%$ of childbirths in Brazil occur within healthcare institutions and official figures reveal that the rates of caesarean sections in public services reach $52 \%{ }^{(1)}$ and over $80 \%$ in the private sector, numbers without a correspondent elsewhere in the world ${ }^{(2)}$.

Within this context and aiming at reversing such scenario, for some years the Ministry of Health has been developing and implementing programs and measures to encourage normal and humanizing childbirth in order to redeem the role of women and also to contribute to improve health indicators.

Therefore, a movement can be currently observed to encourage the modification of the childbirth care model in Brazil, whose political issues involved in this process are in open discussion.

Concerning the delivery institutionalization, figures reveal that a small percentage of childbirths which do not occur in healthcare institutions represent urgency and/or unplanned childbirths, and they often occur in places where access to such services is delayed and precarious.

Nevertheless, within this small percentage of non-institutionalized deliveries, there is an increasing proportion of childbirths which are assisted by qualified healthcare professionals and scheduled in advance to occur at home.

Although representing a slight portion as compared to the total of institutionalized childbirths, home childbirth has been the subject of increasing discussions in the media, social networks, among professional healthcare councils and the most diverse sectors of the society over recent years.

The great controversy involved in home childbirth occurs because it is considered by contemporary medicine as a retrocession both to advancements and the many resources currently available at healthcare services, risking the health of both women and newborns. At this point, the different perspectives on the delivery and childbirth process confront.

\section{OBJECTIVE}

In view of the aforementioned, the aim of this theoretical and reflective study was to present a brief overview of home childbirth care throughout the world, also questioning the reality of the contemporary Brazilian obstetric setting.

\section{MAIN ISSUE OF REFLECTION}

In Brazil, women who currently opt for home childbirths are socially acknowledged as irresponsible and followers of a fad. The professionals involved in this setting receive little encouragement and/or they are even pursued by their own regulatory councils.

Such fact demonstrates that society still does not understand well the reasons leading a woman to choose the home environment to give birth, renouncing the current technology, modernity, comfort and security which are supposedly provided by hospitals/maternities.

Based on a brief consideration of home childbirth accordingly to the world scenario, it is known that in countries such as the Netherlands, Canada and Australia, home childbirth is not only an acknowledged event, but also it is encouraged by the public health care system. This occurs because in these countries, home childbirth is considered a modality of care as safe as the hospital childbirth; it is a satisfactory experience both for women and their families and, most of all, it is a potentially cheaper service to the State. Such issues compose the major reasons for supporting and encouraging home childbirth in these countries. ${ }^{(3-5)}$.

Confirming the experience of these countries, the international scientific literature has demonstrated through recent studies that obstetric and perinatal outcomes are similar when comparing the places selected for delivery, breaking up the current concept that home childbirth offers a greater risk both to mother and baby as compared to hospital childbirth ${ }^{(6-11)}$.

The outcomes achieved demonstrate that low-risk planned home childbirth is associated with lower rates of severe maternal morbidity, postpartum hemorrhaging and manual removal of the placenta $^{(7)}$, low rates of obstetric interventions ${ }^{(11)}$, and no increase in perinatal mortality rates ${ }^{(6,8-11)}$.

Therefore, studies clearly state that the planned low-risk home childbirth assisted by well trained professionals and in the presence of an 
adequate reference and transportation system presents favorable results and may be considered as safe as hospital childbirth, as there is no evidence for an increased risk of serious adverse outcomes for women under these conditions ${ }^{(8-11)}$.

The most recent review of the literature on the subject published by the Cochrane Library compared the effects on rates of interventions, complications and mortality of hospital childbirth versus planned home childbirth ${ }^{(12)}$. Although this review has not found a sufficient sample of studies to establish a statistically based conclusion, the authors concluded that there is no evidence in favor of planned hospital childbirth for low-risk women; therefore there are no evident reasons to discourage home childbirths for this group. The authors also highlight the outcomes achieved through consistent observational studies which demonstrate the advantages related to planned home childbirth ${ }^{(12)}$.

Although scarce, national studies present significant obstetric and neonatal outcomes similar to those achieved in international studies. These findings displayed a decreased rate of hospital transfer, as well as, a reduced need for cesarean sections, perineal trauma and use of medications both during labor and in the postpartum period. In addition, in home childbirths there is high a percentage of use of the vertical position during labor and delivery periods, skin-to-skin contact and breastfeeding in the very first hour after birth ${ }^{(13-14)}$, and all these actions are encouraged by national and international organizations for safe and humanizing delivery care.

Therefore, the outcomes found in the literature contribute both to the dissemination and reliability of this modality of care, in addition to giving increased visibility to the autonomous performance of nurse midwives in childbirth care.

Giving birth at home is a sudden rupture with the current model of obstetric care, which is characterized by the massive use of technology, also embedding a large number of unnecessary interventions and which is often permeated by the silent obstetric violence.

A national research conducted in 2010 by the Perseu Abramo Foundation, in partnership with SESC, pointed out such gloomy scenario. Its outcomes suggest that one in every four women $(25 \%)$ reported having experienced some sort of violence during childbirth. Among the various possible forms of abuse and mistreatment, there were mentions of painful touch examination, refusal to relieve pain, no explanation of the procedures adopted, shouting of professionals, denial of providing care, swearing and humiliations ${ }^{(15)}$.

Historically, childbirth was initially assisted by lay and/or traditional midwives in the Brazilian obstetric care, and it occurred at home. It was a familiar and female event.

At the time when childbirth became an institutional event managed by medical professionals in the mid-twentieth century, the concepts and logic of its conduction changed. Gradually, a perspective of childbirth as associated with pathology, risk and suffering was socially constructed. Such was of understanding and assisting childbirths was incorporated to medical schools, characterizing the phenomenon of pregnancy/childbirth as a process that is not related to healthcare but to illness. This concept still prevails nowadays and it may be considered as a second moment of obstetric care in Brazil.

Contrary to this perspective, women who wish to give birth at home understand delivery as a pleasant, intimate and familiar experience, which is inherent to the female body. They are women who want to redeem their role, experiencing delivery to its fullest and, even when facing so many existing negative social constructions, they can manage to have a glimpse of the excitement and beauty derived from the experience of giving birth.

It is possible to say that this is a phase of obstetric care characterized by the redemption of the holistic delivery process by women who are deeply unhappy with the current care model. These women and families are looking for support through quality information. They hit the streets to claim for evidence-based practices and to denounce the obstetric violence experienced by them and which is still present in most healthcare institutions.

Therefore, in addition to their role, these women also redeem their decision-making power over their bodies and their choices, also taking responsibility for the risks and benefits associated with home childbirth.

The lack of naturalness associated with childbirth causes women who choose to experience it to be constantly victims of threats, teasing and blackmail by a dominating, alienating and cruel system.

Therefore, we believe that giving birth at home seems to belong to a movement of response to institutional violence, fragmentation and depersonalization of hospital care. Would these women be building a new chapter in the Brazilian obstetric care? 


\section{CONCLUSIONS}

Scientific literature clearly points out that home childbirth is a modality of service already consolidated in several countries throughout the world, and it brings favorable obstetric and neonatal outcomes in order to legitimize its practice. In Brazil, it is a poorly explored and increasing option, which is probably reflected in a movement of protest against the conventional obstetric care, in which women search for a more dignified, respectful and humanizing childbirth.

\section{REFERENCES}

1 Ministério da Saúde (BR), Rede Interagencial de Informações para a Saúde [Internet]. Indicadores e dados básicos - Brasil - 2011: F. Indicadores de cobertura . [citado 2013 nov 20] Disponível em: http://tabnet. datasus.gov.br/cgi/idb2011/matriz.htm\#cober

2 Dias MAB. Humanização do parto: política pública, comportamento organizacional e ethos profissional. Cad Saúde Pública 2011;27(5):1042-3.

3 Walsh S, Blijden J. Having a baby in Netherlands [Internet]. The Hague: Access; 2012. [citado 2013 nov 21]. Disponível em: www.access-nl.org/ media/13946/faq_guide_having_a_baby_in_the_netherlands_-_july_2012.pdf

4 Ontario Hospital Association (OHA), College of Midwives of Ontario and Association of Ontario Midwives. Resource manual for sustaining quality midwifery services in Hospitals. Ontário (CA); 2010, 241p.

5 Government of South Australia. Department of Health. Planned birth at home: policy. Adelaide; 2007 [ citado 2013 mar 10]. Original version. Disponível em: http:// www.health.sa.gov.au/PPG/Default.aspx?tabid=189

6 Kennare RM, Keirse MJNC, Tucker GR, Chan AC. Planned home and hospital births in South Australia, 1991-2006: differences in outcomes. Med J Aust. 2010;192(2):76-80.

7 Jonge A, Mesman JAJM, Manniën J, Zwart JJ, van Dillen J, van Roosmalen J. Several adverse maternal outcomes among low risk women with planned home versus hospital births in the Netherlands: nationwide cohort study. Brit Med J. 2013 June 13;346:f3263.

8 Birthplace in England Collaborative Group. Perinatal and maternal outcomes by planned place of birth for healthy women with low risk pregnancies: the Birthplace in England national prospective cohort study. BMJ 2011 Nov 23;343:d7400.

9 Wax JR, Lucas FL, Lamont M, Pinette MG, Cartin A, Blackstone J. Maternal and newborn outcomes in planned home birth vs planned hospital births: a metaanalysis. Am J Obstet Gynecol. 2010; 203(3):243.e1-8. Erratum in: Am J Obstet Gynecol. 2011 Apr;204(4):e7-13.

10 Hutton EK, Reitsma AH, Kaufman K. Outcomes associated with planned home and planned hospital births in low-risk women attended by midwives in Ontario, Canada, 2003-2006: a retrospective cohort study. Birth 2009;36(3):180-9.

11 De Jonge A, Van der Goes BY, Ravelli AC, Amelink-Verburg MP, Mol BW, Nijhuis JG et al. Perinatal mortality and morbidity in a nationwide cohort of 529,688 low-risk planned home and hospital births. BJOG 2009;1 16(9):1 177-84.

12 Olsen O, Jewell MD. El nacimiento en casa frente al nacimiento en el hospital. La Biblioteca Cochrane Plus [Internet]. 2008 [citado 2013 fev 10];(2). Disponível em: http://summaries.cochrane.org/es/CDoo0352/el-nacimiento-en-casa-frente-al-nacimiento-en-el-hospital

13 Koettker JG, Brüggemann OM, Dufloth RM, Knobel R, Monticelli M. Resultado de partos domiciliares atendidos por enfermeiras de 2005 a 2009 em Florianópolis, SC. Rev Saúde Publica 2012;46(4):747-50.

14. Colacioppo PM, Koiffman MD, Gonzalez Riesco ML, Schneck CA, Osava RH. Parto domiciliar planejado: resultados maternos e neonatais. Rev Enf Ref. 2010;3(2):81-90.

15 Fundação Perseu Abramo, Núcleo de Opinião Pública. Gravidez, filhos e violência institucional no parto. In: Mulheres brasileiras e gênero nos espaços público e privado: pesquisa de opinião pública. São Paulo: Fundação Perseu Abramo; 2010 [citado 2013 jun 10]. Disponível em: http://csbh.fpabramo.org.br/node/7247

Received: 24.07.2013

Approved: 31.01 .2014

\section{Author's address / Endereço do autor / Dirección del autor}

Clara Fróes de Oliveira Sanfelice

Rua Pedro Guidotti, 283, Guará

130854-410, Campinas, SP

E-mail: clara_sanfelice@yahoo.com.br 